\title{
RZECZOWE ZARZĄDZANIE ZYSKIEM JAKO INSTRUMENT KSZTAŁTOWANIA DUŻYCH STRAT W PRZEDSIĘBIORSTWACH PRZEMYSŁOWYCH
}

\section{Michał Comporek* \\ REAL EARNINGS MANAGEMENT AS A TOOL FOR BIG BATH CREATING IN INDUSTRIAL COMPANIES}

\begin{abstract}
The purpose of the article/hypothesis: The aim of the paper is to show the importance of the implemented real earnings management (REM) in the intentional shaping of large losses in public industrial enterprises listed on the Warsaw Stock Exchange.

Methodology: The basic method of assessing the REM activities was compliant with the Roychowdhury methodology, enabling the estimation of the abnormal levels of: operational cash flows, production costs and discretionary expenses. In turn, the modified verision of iosik model was used to assess the impact of REM practices on the frequency of large losses in tested sample. Results of the research: The obtained results show that the REM implemented by means of overproduction, granting above-average rebates and a liberal approach in the field of trade credits may be considered an important path of intentional deepening of the net loss in public industrial companies.
\end{abstract}

Keywords: real earnings management, big bath, industrial enterprises, Warsaw Stock Exchange, Roychowdhury models.

JEL Class: G30, M41, M42.

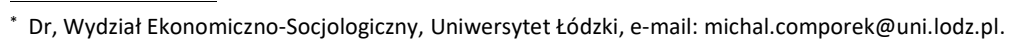




\section{WSTĘP}

Jednym z najważniejszych wyzwań stojących przed współczesną rachunkowością jest uwzględnienie zróżnicowanych oczekiwań poszczególnych grup interesariuszy podmiotu gospodarczego względem jakości informacji zawartych w raportowanych danych. Jak pokazuje praktyka gospodarcza, zewnętrzni odbiorcy informacji sprawozdawczej oczekują nie tylko wiarygodności i przejrzystości prezentowanych danych księgowych, ale również włączenia do systemu rachunkowości pewnych narzędzi pozwalających na estymację poziomu sztucznego kreowania pozycji finansowej i wyceny przedsiębiorstw. Zauważono bowiem, że postępująca utrata wartości poznawczej tradycyjnych wskaźników ekonomicznych oraz kryzys zaufania w biznesie, będący pokłosiem implementowanych działań z zakresu rachunkowości kreatywnej i/lub agresywnej (Kiziukiewicz i in., 2009: 37-38), prowadzić może m.in. do powszechnych rozbieżności pomiędzy wartością rynkową a księgową przedsiębiorstw, błędnych analiz zdolności płatniczej podmiotów rynkowych oraz perspektyw ich rozwoju, niemożnością stworzenia rzetelnej bazy informacyjnej do oceny standingu finansowego emitentów papierów wartościowych itd.

Za syntetyczny miernik oceny działalności jednostek gospodarczych, a jednocześnie miarę, która w szczególny sposób podatna jest na intencjonalne kształtowanie, uznać należy wynik finansowy przedsiębiorstwa. Kategoria ta odzwierciedla nie tylko finansowe efekty gospodarcze płynące $\mathrm{z}$ jej działalności, lecz także wskazuje na wartość podejmowanych i realizowanych przez nie poczynań w sferze społecznej i kulturowej (Comporek, 2020: 8). Zarządzanie wynikiem finansowym (dalej utożsamiane ze zjawiskiem earnings management) może być nakierowane na osiągnięcie zróżnicowanych celów, aktualnych z perspektywy określonego momentu funkcjonowania przedsiębiorstwa. Choć powszechnie przyjmuje się, że implementacja tego typu praktyk generalnie służyć ma ukazaniu najkorzystniejszego wizerunku podmiotu gospodarczego, to motywy i konsekwencje wynikające $\mathrm{z}$ podjętych działań w tym zakresie mogą być różnorodne: począwszy od sztucznego zawyżania raportowanego zysku netto, poprzez jego „wygładzanie” w celu uniknięcia „,wzlotów” i ,upadków” po stronie wykazywanego wyniku w kolejnych okresach obrachunkowych, a skończywszy na świadomym pogłębianiu osiągniętej już straty netto.

Zasadniczym celem artykułu jest ukazanie znaczenia wdrażanych praktyk z obszaru rzeczowego (realnego) zarządzania wynikiem finansowym (real earnings management - REM) $\mathrm{w}$ intencjonalnym kształtowaniu dużych strat $\mathrm{w}$ publicznych przedsiębiorstwach przemysłowych notowanych na GPW w Warszawie. Nakreślona optyka badawcza koncentruje się na wyselekcjonowaniu określonych technik real earnings management (wyznaczanych zgodnie z metodologią Roychowdhury), które w największej mierze przyczyniają się do świadomego 
pogłębiania dużych strat w spółkach giełdowych poddanych analizie. Dla operacjonalizacji przyjętego celu pracy stworzona została hipoteza badawcza twierdząca, że wartości współczynników opisujących skalę działań na płaszczyźnie rzeczowego zarządzania zyskiem są w sposób istotny statystycznie powiązane z częstotliwością występowania dużych strat w badanej populacji. Dla porządku podkreślić należy, że zgodnie z przyjętą metodyką badań o fakcie występowania wielkiej straty w podmiocie gospodarczym będzie mowa wówczas, gdy raportowana strata netto przewyższała wartość $10 \%$ sumy bilansowej w analizowanym roku obrotowym.

Badania empiryczne zrealizowano w gronie 80 przedsiębiorstw prowadzących działalność wytwórczą, których akcje były przedmiotem obrotu na giełdzie przez okres minimum 10 lat w przyjętym horyzoncie odniesienia 2002-2018. Dodatkowym kryterium doboru podmiotów do badań były: kompletność raportowanych danych oraz dostępność rocznych jednostkowych sprawozdań finansowych. Poczynione analizy bazowały na informacjach zaczerpniętych z bazy danych Notoria Serwis SA.

\section{WIELKA KAPIEL KOSZTOWA (BIG BATH CHARGES) JAKO STRATEGIA KSZTALTOWANIA WYNIKU FINANSOWEGO PRZEDSIĘBIORSTW}

Całokształt wyodrębnianych w literaturze przedmiotu strategii zarządzania wynikiem finansowym hierarchizować można m.in. ze względu na konsekwencje (uzyskane rezultaty) wynikające z podjętych działań z zakresu earnings management. W ten sposób do głównych sposobów kształtowania wyniku w przedsiębiorstwie zaliczyć można: strategię wygładzania zysku (income smoothing), strategię upiększania wyników (window dressing), jak również strategię wielkiej kąpieli kosztowej (big bath charges) (zob. rys. 1).

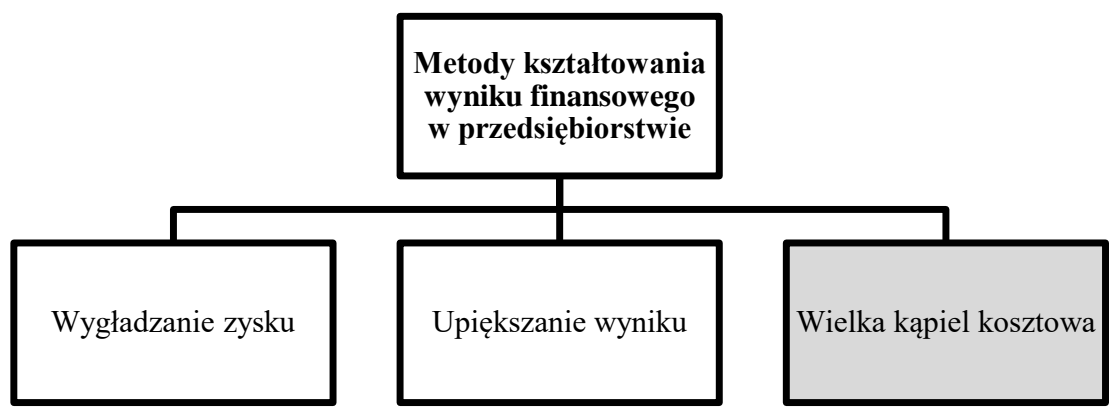

Rysunek 1. Główne strategie kształtowana wyniku finansowego, wydzielane ze względu na motyw implementowanych działań zarządzania zyskiem

Źródło: opracowanie własne na podstawie: Comporek, 2020: 31-40. 
Strategia implementowania wielkiej kąpieli kosztowej w przedsiębiorstwie wiąże się z istotną redukcją dotąd wypracowanego, niesatysfakcjonującego poziomu wyniku finansowego w celu umożliwienia jego „sztucznego" wzrostu w przyszłości. Tokuga i Yamashita (2011: 123-138) określają ją jako „próbę zwiększenia raportowanych zysków w kolejnych okresach poprzez bieżące obciążanie tych pozycji, które mogą mieć negatywny wpływ na raportowany wynik finansowy w przyszłości. Przy czym, działania te pogarszają i tak słabe wyniki biznesowe osiągnięte $\mathrm{w}$ analizowanym okresie". W ten sposób zauważyć można, że wielka kąpiel kosztowa wiąże się ze strategią negatywnego oddziaływania na niezadawalające poziomy uzyskiwanych wyników finansowych drogą generowania nadzwyczajnie wysokich poziomów kosztów w danym segmencie działalności przedsiębiorstwa w okresie bieżącym, z jednoczesnym dążeniem do ograniczania poziomu tych kosztów w okresach kolejnych. Przy czym, jest ona szczególnie często utożsamiana $\mathrm{z}$ intencjonalnymi działaniami dążącymi do pogłębiania osiągniętej już straty netto.

Dominujące podejścia do identyfikacji procesów big bath wiążą się z oceną skutków stosowania określonych instrumentów rachunkowości w następnych latach obrotowych po znacznej redukcji wyniku (np. odwracanie niewykorzystanych rezerw, odwracanie rozliczeń międzyokresowych biernych, odpisów z tytułu utraty wartości aktywów trwałych itd.) lub analizą redukcji wyników na podstawie oceny dokonań okresu, w którym wielka kąpiel kosztowa została zrealizowana. W obu przypadkach możliwości estymacji rozmiaru tego typu praktyk są ograniczone (Piosik, 2016: 26-27). Dominującym motywem wdrażania tychże praktyk jest przeświadczenie, że uczestnicy rynku mogą wykazywaną wysoką stratę finansową potraktować jako zdarzenie jednorazowe i w większym stopniu skoncentrować swoją uwagę na wycenie wartości spółki w oparciu o prognozy dotyczące przeszłych zysków. W wielu przypadkach tego rodzaju działania są także determinowane niskimi pobudkami menedżerów, dążących do uwydatnienia skuteczności swoich działań w kolejnych okresach (sytuacja ta dotyczy zwłaszcza okresów, w których dochodzi do zmian kadry kierowniczej przedsiębiorstwa).

W opracowaniu przyjęto, że o występowaniu dużej straty finansowej będzie można mówić wówczas, gdy raportowany, bezwzględny poziom straty netto na koniec roku obrachunkowego przekroczył 10\% wartości sumy bilansowej przedsiębiorstwa (Barth i in., 2008: 467-498). Do oceny czynników wpływających na częstotliwość występowania dużych strat w spółkach wytwórczych posłużył zmodyfikowany model Piosika (2013: 145). Jego postać jest następująca, a mianowicie: 


$$
\begin{aligned}
\text { BIGBATH }_{t}=\alpha_{0} & +\alpha_{1} R E M_{t}+\alpha_{2} \operatorname{lnTA}_{t}+\alpha_{3}\left(\frac{O C F_{t-1}}{T A_{t}}\right)+\alpha_{4}\left(\frac{\Delta R E V_{t}}{T A_{t}}\right)+\alpha_{5} L E V_{t} \\
& +\alpha_{6}\left(\frac{O N C A_{t}}{T A_{t}}\right)+\alpha_{7}\left(\frac{\Delta L T L_{t}}{T A_{t}}\right)+\alpha_{8}\left(\frac{\Delta E Q E_{t}}{T A_{t}}\right)+\alpha_{9} F D_{t}+\alpha_{10} \Delta R E T_{t} \\
& ++\alpha_{11} D_{t}+\varepsilon_{t}
\end{aligned}
$$

gdzie:

$B I G B A T H_{t}-$ zmienna zerojedynkowa (wynosząca 1 - gdy strata netto wynosiła $>10 \%$ sumy aktywów w roku $t$ lub $0-$ w przeciwnym razie);

$R E M_{t} \quad-$ wybrany współczynnik realnego zarządzania zyskiem obliczony dla roku $t$;

$\ln T A_{t} \quad-$ logarytm naturalny sumy aktywów na koniec roku $t$;

$O C F_{t} \quad-$ operacyjne przepływy pieniężne w roku $t$;

$R E V_{t} \quad-$ przychody ze sprzedaży w roku $t$;

$L E V_{t} \quad-$ wartość zobowiązań ogółem do sumy aktywów na koniec roku $t$;

$O N C A_{t} \quad-$ suma aktywów operacyjnych na koniec roku $t$;

$\triangle L T L_{t} \quad-$ przyrost zobowiązań długoterminowych w roku $t$;

$\triangle E Q E_{t} \quad-$ przyrost kapitału własnego pomniejszonego o zyski netto w roku $t$;

$\triangle R E T_{t} \quad-$ zmiana poziomu zysków zatrzymanych w roku $t$;

$\mathrm{DSH}_{t} \quad$ - zmienna zerojedynkowa (wynosząca 1 - gdy występuje akcjonariusz dominujący posiadający $>50 \%$ akcji lub $0-$ w przeciwnym razie);

$F D_{t} \quad-$ zmienna binarna (wynosząca -1 - gdy wartość zmiennej sztucznej według modelu dyskryminacyjnego Hamrola i in. (2004: 35-39) w roku t stanowiła $<0$ lub $0-$ w przeciwnym razie).

\section{UMIEJSCOWIENIE INSTRUMENTÓW RZECZOWEGO KSZTAŁTOWANIA WYNIKU FINANSOWEGO W DUALNYM WYMIARZE KONCEPCII EARNINGS MANAGEMENT}

Podkreślany w literaturze przedmiotu dwojaki charakter technik kreacji wyniku finansowego wyraża implicite postulat twórczej i niestandardowej interpretacji obowiązujących zasad rachunkowości wraz z podniesionymi obawami naruszenia standardów rachunkowości w procesach przetwarzania i prezentacji zdarzeń gospodarczych. Wspomniane techniki zarządzania wynikiem finansowym w szerokim ujęciu pozwalają na wydzielenie instrumentów i narzędzi kształtowania tegoż wyniku zgodnie z przyjętymi zasadami i szacunkami w rachunkowości, jak i z uwzględnieniem strukturalizacji transakcji gospodarczych. O ile pierwsza z wymienionych koncepcji integralnie łączy się z zasadami tzw. rachunkowego 
zarządzania zyskiem (accrual-based earnings management), o tyle druga z nich nawiązuje do zagadnień rzeczowego (realnego) kształtowania wyniku finansowego przedsiębiorstwa (zob. rys. 2).

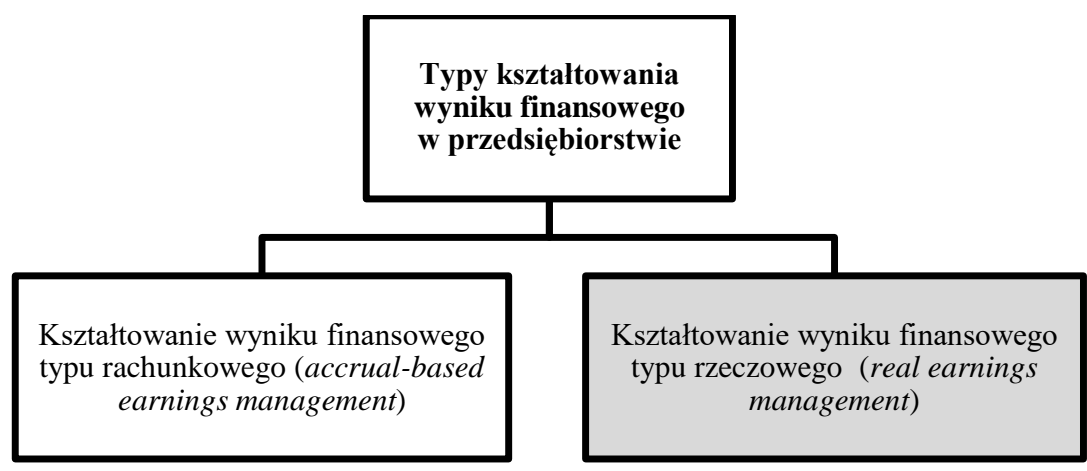

Rysunek 2. Dwuwymiarowy model intencjonalnego kształtowania wyniku finansowego w przedsiębiorstwie

Źródło: opracowanie własne.

Zdaniem Ewerta i Wagenhofera (2005: 1104) praktyki realnego zarządzanie zyskiem mają miejsce wówczas, gdy menedżerowie podejmują transakcje nieefektywne z punktu widzenia firmy, ale generujące pożądany poziom zysku lub straty w bieżącym okresie. Sellami (2005: 207) dodaje przy tym, iż z narzędziowego punktu widzenia działania podejmowane na płaszczyźnie $R E M$ wiążą się z zamierzoną, czasową koordynacją oraz strukturyzowaniem procesów gospodarczych (związanych z działalnością operacyjną, inwestycyjną lub finansową), dzięki czemu można bezpośrednio wpływać na wartość generowanych przepływów pieniężnych i wynik finansowy okresu. Jednocześnie zabiegi te są motywowane dążeniami kierownictwa do wprowadzenia w błąd zainteresowanych stron o rzeczywistych wynikach firmy. Jak widać z zaprezentowanego ujęcia terminologicznego, realne kształtowanie wyniku finansowego jest oceniane w sposób jednoznacznie negatywny (zob. m.in.: Schipper, 1989: 92; Vladu, 2015: 404; Comporek, 2019: 144). Działania te, oprócz atrybutów tradycyjnie im przypisywanych (takich jak: wykorzystanie nietypowych, odmiennych od powszechnie stosowanych transakcji gospodarczych, wysoce kosztochłonna implementacja, czy też możliwość wdrażania praktycznie w całym okresie trwania roku obrachunkowego) odznaczają się jeszcze jedną istotną z zarządczego punktu widzenia cechą - mianowicie, nie podlegają praktycznie żadnemu zewnętrznemu systemowi kontroli, przez co są trudne do identyfikacji i wykrycia. W ten sposób niezwykle 
trudne staje się również oszacowanie skali i kierunków tego typu praktyk w przedsiębiorstwie.

Propozycje metodologiczne estymacji praktyk rzeczowego zarządzania wynikiem finansowym odnaleźć można m.in. w pracach: McVay (2006: 501-531), Gunny (2010: 855-888), Mizik (2010: 594-611) czy też Chakravarty i Grewala (2011: 1594-1609). W niniejszym opracowaniu do oszacowania skali działań z zakresu REM wykorzystano metodologię Roychowdhury (2006: 335-370), która pozwala na wyodrębnienie trzech sfer rzeczowego oddziaływania na wynik finansowy, przedstawionych za pomocą współczynników: ponadprzeciętnego poziomu operacyjnych przepływów pieniężnych (abnormal cash flow from operations - DISC_OCF), ponadprzeciętnego poziomu kosztów produkcji (abnornal cost of good sold and changes in inventory; discretionary production DISC_PROD) oraz ponadprzeciętnego poziomu kosztów sprzedaży i ogólnego zarządu W przedsiębiorstwie (abnormal discretionary expenditures $\left.D I S C \_S G \& A\right)$. Formuły analityczne tychże modeli przewidują, iż o skali $R E M$ świadczyć będą odchylenia in minus współczynników DISC_OCF i DISC_SG\&A od zera, jak również odchylenia in plus miary DISC_PROD od zera. Z kolei ogólny poziom praktyk rzeczowego kształtowania wyniku finansowego wyznaczany jest na podstawie wartości składników resztowych poszczególnych modeli regresyjnych. Zgodnie z założeniami Roychowdhury, szczególne znaczenie w estymacji praktyk REM przypada kategorii przychodów ze sprzedaży, która stanowi najważniejszą zmienną egzogeniczną w trzech rozpatrywanych modelach regresyjnych:

$$
\begin{gathered}
\frac{O C F_{t}}{T A_{t-1}}=\alpha_{1}\left(\frac{1}{T A_{t-1}}\right)+\alpha_{2}\left(\frac{R E V_{t}}{T A_{t-1}}\right)+\alpha_{3}\left(\frac{\Delta R E V_{t}}{T A_{t-1}}\right)+\varepsilon_{t}^{\text {DISC_OCF }} \\
\frac{P R O D_{t}}{T A_{t-1}}=\alpha_{0}+\alpha_{1}\left(\frac{1}{T A_{t-1}}\right)+\alpha_{2}\left(\frac{R E V_{t}}{T A_{t-1}}\right)+\alpha_{3}\left(\frac{\Delta R E V_{t}}{T A_{t-1}}\right)+\alpha_{4}\left(\frac{\Delta R E V_{t-1}}{T A_{t-1}}\right) \\
+\varepsilon_{t}^{\text {DISC_PROD }} \\
\frac{S G \& A_{t}}{T A_{t-1}}=\alpha_{1}\left(\frac{1}{T A_{t-1}}\right)+\alpha_{2}\left(\frac{R E V_{t-1}}{T A_{t-1}}\right)+\varepsilon_{t}^{\text {DISC_SG\&A }}
\end{gathered}
$$

gdzie:

$\mathrm{PROD}_{t} \quad-$ wartość kosztów produkcji w roku $t$;

$S G \& A_{t} \quad-$ wartość kosztów ogólnego zarządu i kosztów sprzedaży w roku $t$; $\alpha_{1}, i=0,1, \ldots, k-$ parametry modelu regresji;

$\varepsilon_{t}^{D I S C_{-} O C F} \quad-$ reszta $\mathrm{z}$ modelu regresji, równa dyskrecjonalnym operacyjnym przepływom pieniężnym - DISC_OCF; 
$\varepsilon_{t}^{D I S C_{-} P R O D}$

- reszta z modelu regresji, równa dyskrecjonalnym kosztom produkcji - DISC_PROD;

$\varepsilon_{t}^{D I S C_{-} S G \& A} \quad-$ reszta $\mathrm{z}$ modelu regresji, równa dyskrecjonalnym kosztom sprzedaży i ogólnego zarządu - DISC_SG\&A;

pozostałe oznaczenia - jak uprzednio.

Przekształcając otrzymane trzy współczynniki REM w jeden wskaźnik syntetyczny TOT_REM, możliwa staje się ocena całokształtu działań wdrażanych przez przedsiębiorstwo w zgodzie z koncepcją realnego kształtowania wyniku finansowego. Model syntetyczny przyjmuje, iż im większe będą wartości współczynnika TOT_REM, tym podmiot gospodarczy jest w większym stopniu zaabsorbowany wdrażaniem opisywanych praktyk earnings management, zaś jego postać jest następująca:

$$
T O T \_R E M=-D I S C \_O C F+D I S C_{-} P R O D-D I S C \_S G \& A
$$

gdzie:

$T O T \_R E M$ - współczynnik całkowitego realnego zarządzania wynikiem finansowym;

pozostałe oznaczenia - jak uprzednio.

\section{WYNIKI BADAŃ EMPIRYCZNYCH}

W rozpatrywanych modelach regresji logistycznej zmienna zależna reprezentowana jest przez zmienną dychotomiczną, gdzie: 1 - to wartość wyróżniona, oznacza wystąpienie dużej straty w przedsiębiorstwie w analizowanym roku obrotowym, zaś 0 - oznacza, że wspomniana strata nie wystąpiła. Już w tym miejscu należy zasygnalizować, iż stratę netto wynoszącą powyżej 10\% wartości sumy aktywów zanotowano w przypadku 5,6\% obserwacji (56 spośród 996 wszystkich analizowanych przypadków). W celu weryfikacji poprawności modelów przeprowadzono test ilorazu wiarygodności - test zbiorowy współczynników w modelu chi-kwadrat z liczbą stopni swobody równą liczbie zmiennych w szacowanym modelu. Z kolei do oszacowań stopnia dopasowania modelu do danych empirycznych posłużyły współczynniki determinacji: Coxa i Snella oraz Nagelkerkego. Weryfikację poprawności modelu przeprowadzono także za pomocą testu Hosmera-Lemeshowa, przy czym w przypadku tego testu pożądany jest brak istotności (Kmieć, 2015: 37). W każdym z czterech analizowanych przypadków uzyskane wartości współczynników determinacji świadczą o podobnym, przeciętnym stopniu dopasowaniu modelu do danych empirycznych (dodatkowo wprowadzenie zmiennych wpływa na poprawę jakości modelu). Podobnie, we wszystkich czterech testowanych modelach logistycznych otrzymano satysfakcjonujące 
wyniki testu Hosmera-Lemeshowa, weryfikującego hipotezę o równości wartości obserwowanych i przewidywanych. Wskazują one, że przy przyjętym poziomie istotności $\alpha=0,05$ nie ma podstaw do odrzucenia hipotezy zerowej. Klasy nie różnicują dopasowania, co jest pożądaną własnością.

Tabela 1. Wieloczynnikowa analiza dużych strat w spółkach giełdowych, uwzględniająca dyskrecjonalne operacyjne przepływy pieniężne $\left(D I S C \_O C F\right)$ jako potencjalny czynnik kreacji wielkiej kąpieli kosztowej

\begin{tabular}{|c|c|c|c|c|c|c|}
\hline \multicolumn{7}{|c|}{ I. Zmienna endogeniczna - BIGBATH } \\
\hline Zmienne & $\mathrm{B}$ & $\begin{array}{c}\text { Błąd } \\
\text { standard. }\end{array}$ & Wald & $\mathrm{df}$ & Ist. & $\operatorname{Exp}(B)$ \\
\hline Stała & $-2,846$ & 1,662 & 2,931 & 1 & 0,087 & 0,058 \\
\hline DISC_OCF & $-5,168$ & 2,212 & 4,459 & 1 & $\mathbf{0 , 0 1 9}$ & 0,006 \\
\hline $\operatorname{lnTA}$ & $-0,069$ & 0,131 & 0,274 & 1 & 0,600 & 0,934 \\
\hline $\mathrm{OCF}_{\mathrm{t}-1} / \mathrm{TA}_{\mathrm{t}}$ & $-0,214$ & 1,692 & 0,016 & 1 & 0,899 & 0,807 \\
\hline$\Delta \mathrm{REV}_{\mathrm{t}} / \mathrm{TA}_{\mathrm{t}}$ & $-1,039$ & 0,518 & 4,025 & 1 & 0,045 & $\mathbf{0 , 3 5 4}$ \\
\hline $\mathrm{LEV}_{\mathrm{t}}$ & $-1,495$ & 0,783 & 3,645 & 1 & 0,056 & 0,224 \\
\hline $\mathrm{ONCA}_{t} / \mathrm{TA}_{\mathrm{t}}$ & 0,215 & 1,014 & 0,045 & 1 & 0,832 & 1,240 \\
\hline$\Delta \mathrm{LTL}_{\mathrm{t}} / \mathrm{TA}_{\mathrm{t}}$ & 1,651 & 1,355 & 1,484 & 1 & 0,223 & 5,210 \\
\hline$\Delta \mathrm{EQE}_{\mathrm{t}} / \mathrm{TA}_{\mathrm{t}}$ & 0,332 & 1,085 & 0,094 & 1 & 0,760 & 1,394 \\
\hline FD $_{\mathbf{t}}$ & $-4,907$ & 0,467 & 110,402 & 1 & $\mathbf{0 , 0 0 0}$ & $\mathbf{0 , 0 0 7}$ \\
\hline$\Delta \mathrm{RET}_{\mathrm{t}}$ & 0,000 & 0,007 & 0,000 & 1 & 0,996 & 1,000 \\
\hline $\mathrm{DSH}_{\mathrm{t}}$ & $-0,578$ & 0,426 & 1,837 & 1 & 0,175 & 0,561 \\
\hline \multicolumn{3}{|c|}{ Podsumowanie modelu } & \multicolumn{4}{|c|}{ Test Hosmera i Lemeshowa } \\
\hline Coxa i Snella $\mathrm{R}^{2}$ & \multicolumn{2}{|c|}{ Nagelkerkego $\mathrm{R}^{2}$} & Chi-kwadrat & \multicolumn{2}{|c|}{ df } & Ist. \\
\hline 0,190 & \multicolumn{2}{|c|}{\begin{tabular}{|l|l|}
0,542 & \\
\end{tabular}} & 5,405 & \multicolumn{2}{|c|}{8} & 0,714 \\
\hline \multicolumn{7}{|c|}{ Test zbiorowy wspótczynników w modelu } \\
\hline \multicolumn{2}{|c|}{ Chi-kwadrat } & \multicolumn{2}{|r|}{ df } & & \multicolumn{2}{|c|}{ Ist. } \\
\hline \multicolumn{2}{|c|}{211,724} & \multicolumn{2}{|r|}{11} & & \multicolumn{2}{|c|}{0,000} \\
\hline
\end{tabular}

Źródło: opracowanie własne.

Z analizy wyników badań empirycznych zaprezentowanych w tabeli 1 wynika, iż kształtowanie wyniku finansowego drogą manipulacji wolumenem sprzedaży przy jednoczesnym spadku poziomu wykazywanych operacyjnych przepływów pieniężnych (zmienna DISC_OCF) może być postrzegane jako istotny (ze statystycznego punktu widzenia) sposób kreowania wysokich strat w przemysłowych spółkach giełdowych. Otrzymane ujemne wartości parametru $\beta$ widniejącego przy zmiennej DISC_OCF potwierdzają założenie, że z analitycznego 
punktu widzenia o skali implementowanych praktyk REM w jednostce gospodarczej świadczą odchylenia in minus wartości dyskrecjonalnych operacyjnych przepływów pieniężnych od zera (Roychowdhury, 2006: 335-370).

Tabela 2. Wieloczynnikowa analiza dużych strat w spółkach giełdowych, uwzględniająca dyskrecjonalne koszty produkcji (DISC_PROD) jako potencjalny czynnik kreacji wielkiej kąpieli kosztowej

\begin{tabular}{|c|c|c|c|c|c|c|}
\hline \multicolumn{7}{|c|}{ I. Zmienna endogeniczna - BIGBATH } \\
\hline Zmienne & $\mathrm{B}$ & $\begin{array}{c}\text { Błąd } \\
\text { standard. }\end{array}$ & Wald & df & Ist. & $\operatorname{Exp}(B)$ \\
\hline Stała & $-3,101$ & 1,626 & 3,637 & 1 & 0,057 & 0,045 \\
\hline DISC_PROD & 4,457 & 1,944 & 5,256 & 1 & 0,022 & 86,241 \\
\hline $\operatorname{lnTA}$ & $-0,047$ & 0,127 & 0,138 & 1 & 0,710 & 0,954 \\
\hline $\mathrm{OCF}_{\mathrm{t}-1} / \mathrm{TA}_{\mathrm{t}}$ & $-2,008$ & 1,419 & 2,004 & 1 & 0,157 & 0,134 \\
\hline$\Delta \mathbf{R E V}_{\mathrm{t}} / \mathbf{T A} \mathbf{A}_{\mathbf{t}}$ & $-1,021$ & 0,514 & 3,948 & 1 & 0,047 & 0,360 \\
\hline $\mathbf{L E V}_{\mathbf{t}}$ & $-1,651$ & 0,790 & 4,365 & 1 & $\mathbf{0 , 0 3 7}$ & 0,192 \\
\hline $\mathrm{ONCA}_{\mathrm{t}} / \mathrm{TA}_{\mathrm{t}}$ & 0,252 & 1,014 & 0,062 & 1 & 0,804 & 1,287 \\
\hline$\Delta \mathrm{LTL}_{\mathrm{t}} / \mathrm{TA}_{\mathrm{t}}$ & 2,024 & 1,354 & 2,235 & 1 & 0,135 & 7,570 \\
\hline$\Delta \mathrm{EQE}_{\mathrm{t}} / \mathrm{TA}_{\mathrm{t}}$ & 0,537 & 1,084 & 0,245 & 1 & 0,621 & 1,710 \\
\hline FD $_{\mathbf{t}}$ & $-4,940$ & 0,469 & 110,757 & 1 & 0,000 & 0,007 \\
\hline$\triangle \mathrm{RET}_{\mathrm{t}}$ & 0,001 & 0,007 & 0,007 & 1 & 0,932 & 1,001 \\
\hline $\mathrm{DSH}_{\mathrm{t}}$ & $-0,595$ & 0,430 & 1,915 & 1 & 0,166 & 0,551 \\
\hline \multicolumn{3}{|c|}{ Podsumowanie modelu } & \multicolumn{4}{|c|}{ Test Hosmera i Lemeshowa } \\
\hline Coxa i Snella $\mathrm{R}^{2}$ & \multicolumn{2}{|c|}{ Nagelkerkego $\mathrm{R}^{2}$} & Chi-kwadrat & \multicolumn{2}{|c|}{\begin{tabular}{|c|}
$\mathrm{df}$ \\
\end{tabular}} & Ist. \\
\hline 0,192 & \multicolumn{2}{|c|}{0,546} & 4,074 & \multicolumn{2}{|c|}{8} & 0,850 \\
\hline \multicolumn{7}{|c|}{ Test zbiorowy wspótczynników w modelu } \\
\hline \multicolumn{2}{|c|}{ Chi-kwadrat } & \multicolumn{2}{|r|}{ df } & \multicolumn{3}{|c|}{ Ist. } \\
\hline \multicolumn{2}{|c|}{210,768} & \multicolumn{2}{|r|}{11} & \multicolumn{3}{|c|}{0,000} \\
\hline
\end{tabular}

Źródło: opracowanie własne.

Poczynione analizy wykazały również, iż realne zarządzanie wynikiem finansowym drogą nadprodukcji i sztucznego zwiększenia liczby wytworzonych produktów do poziomu przekraczającego oczekiwany popyt na rynku (zmienna DISC_PROD), może być rozważane jako jedna z potencjalnych ścieżek kształtowania dużych strat $\mathrm{w}$ rozpatrywanej zbiorowości. Otrzymane wartości parametrów strukturalnych zaprezentowane w tabeli 2 wskazują, iż wraz ze wzrostem wartości współczynnika dyskrecjonalnych kosztów produkcji zwiększa się statystyczne prawdopodobieństwo wystąpienia straty netto przekraczającej $10 \%$ sumy bilansowej przedsiębiorstwa. Dodatnia wartość parametru $\beta$ przy zmiennej 
DISC_PROD potwierdza przy tym założenie prezentowane w literaturze przedmiotu, iż o skali praktyk REM świadczyć mogą dodatnie odchylenia współczynnika DISC_PROD od zera.

Tabela 3. Wieloczynnikowa analiza dużych strat w spółkach giełdowych, uwzględniająca dyskrecjonalne koszty sprzedaży i ogólnego zarządu (DISC_SG\&A) jako potencjalny czynnik kreacji wielkiej kąpieli kosztowej

\begin{tabular}{|c|c|c|c|c|c|c|}
\hline \multicolumn{7}{|c|}{ I. Zmienna endogeniczna - BIGBATH } \\
\hline Zmienne & $\mathrm{B}$ & $\begin{array}{c}\text { Błąd } \\
\text { standard. }\end{array}$ & Wald & df & Ist. & $\operatorname{Exp}(B)$ \\
\hline Stała & $-2,865$ & 1,658 & 2,987 & 1 & 0,084 & 0,057 \\
\hline DISC_SG\&A & 2,725 & 2,945 & 0,856 & 1 & 0,355 & 15,256 \\
\hline $\ln \mathrm{TA}$ & $-0,068$ & 0,131 & 0,272 & 1 & 0,602 & 0,934 \\
\hline $\mathrm{OCF}_{\mathrm{t}-1} / \mathrm{TA}_{\mathrm{t}}$ & $-1,779$ & 1,404 & 1,605 & 1 & 0,205 & 0,169 \\
\hline$\Delta \mathbf{R E V}_{\mathrm{t}} / \mathbf{T A} \mathbf{A}_{\mathbf{t}}$ & $-1,060$ & 0,499 & $\mathbf{4 , 5 1 7}$ & 1 & $\mathbf{0 , 0 3 4}$ & 0,347 \\
\hline $\mathrm{LEV}_{\mathrm{t}}$ & $-1,448$ & 0,796 & 3,311 & 1 & 0,069 & 0,235 \\
\hline $\mathrm{ONCA}_{\mathrm{t}} / \mathrm{TA}_{\mathrm{t}}$ & 0,229 & 1,015 & 0,051 & 1 & 0,822 & 1,257 \\
\hline$\Delta \mathrm{LTL}_{\mathrm{t}} / \mathrm{TA}_{\mathrm{t}}$ & 1,957 & 1,355 & 2,084 & 1 & 0,149 & 7,077 \\
\hline$\Delta \mathrm{EQE}_{\mathrm{t}} / \mathrm{TA}_{\mathrm{t}}$ & 0,669 & 1,070 & 0,391 & 1 & 0,532 & 1,952 \\
\hline FD $_{\mathbf{t}}$ & $-4,864$ & 0,462 & 111,003 & 1 & 0,000 & $\mathbf{0 , 0 0 8}$ \\
\hline$\triangle \mathrm{RET}_{\mathrm{t}}$ & 0,000 & 0,007 & 0,002 & 1 & 0,968 & 1,000 \\
\hline $\mathrm{DSH}_{\mathrm{t}}$ & $-0,558$ & 0,425 & 1,723 & 1 & 0,189 & 0,572 \\
\hline \multicolumn{3}{|c|}{ Podsumowanie modelu } & \multicolumn{4}{|c|}{ Test Hosmera i Lemeshowa } \\
\hline Coxa i Snella $\mathrm{R}^{2}$ & \multicolumn{2}{|c|}{ Nagelkerkego $\mathrm{R}^{2}$} & Chi-kwadrat & \multicolumn{2}{|c|}{\begin{tabular}{|c|}
$\mathrm{df}$ \\
\end{tabular}} & Ist. \\
\hline 0,189 & \multicolumn{2}{|c|}{0,538} & 10,916 & \multicolumn{2}{|c|}{8} & 0,207 \\
\hline \multicolumn{7}{|c|}{ Test zbiorowy wspótczynników w modelu } \\
\hline \multicolumn{2}{|c|}{ Chi-kwadrat } & \multicolumn{2}{|r|}{ df } & \multicolumn{3}{|c|}{ Ist. } \\
\hline \multicolumn{2}{|c|}{207,367} & \multicolumn{2}{|r|}{11} & \multicolumn{3}{|c|}{0,000} \\
\hline
\end{tabular}

Źródło: opracowanie własne.

Jednocześnie, na podstawie przeprowadzonych badań empirycznych nie udało się udowodnić, że w spółkach giełdowych poddanych analizie realizowano strategie wykazywania dużych strat drogą manipulacji poszczególnymi kategoriami kosztów uznaniowych (za które w opracowaniu przyjęto: koszty sprzedaży i koszty ogólnego zarządu) (zob. tab. 3). Nienaturalna minimalizacja tychże kosztów (dodatkowo, obejmująca często również ograniczenia nakładów na badania i rozwój) w danym okresie obrachunkowym może być postrzegana jako jeden $\mathrm{z}$ dominujących wymiarów praktyk REM w przedsiębiorstwie. Jednakże, tego 
typu działania są wdrażane przede wszystkim z myślą o intencjonalnym podwyższaniu wykazywanego poziomu wyniku finansowego, stąd też brak statystycznych powiązań między częstotliwością wystąpienia dużych strat a wartościami współczynnika dyskrecjonalnych kosztów uznaniowych $D I S C \_S G \& A$ nie powinien być uznany za zaskoczenie.

Tabela 4. Wieloczynnikowa analiza dużych strat w spółkach giełdowych, uwzględniająca ogół praktyk z zakresu REM (zmienna TOT REM) jako potencjalny czynnik kreacji wielkiej kąpieli kosztowej

\begin{tabular}{|c|c|c|c|c|c|c|}
\hline \multicolumn{7}{|c|}{ I. Zmienna endogeniczna - BIGBATH } \\
\hline Zmienne & $\mathrm{B}$ & $\begin{array}{c}\text { Błąd } \\
\text { standard }\end{array}$ & Wald & df & Ist. & $\operatorname{Exp}(B)$ \\
\hline Stała & $-2,816$ & 1,614 & 3,043 & 1 & 0,081 & 0,060 \\
\hline TOT_REM & 3,040 & 1,476 & 4,242 & 1 & $\mathbf{0 , 0 3 9}$ & 20,912 \\
\hline $\ln \mathrm{TA}$ & $-0,069$ & 0,127 & 0,294 & 1 & 0,588 & 0,934 \\
\hline $\mathrm{OCF}_{\mathrm{t}-1} / \mathrm{TA}_{\mathrm{t}}$ & $-0,907$ & 1,438 & 0,398 & 1 & 0,528 & 0,404 \\
\hline$\Delta \mathbf{R E V}_{\mathrm{t}} / \mathbf{T A}_{\mathrm{t}}$ & $-1,024$ & $\mathbf{0 , 5 1 9}$ & 3,886 & 1 & 0,049 & $\mathbf{0 , 3 5 9}$ \\
\hline LEV $_{t}$ & $-1,670$ & 0,790 & 4,465 & 1 & $\mathbf{0 , 0 3 5}$ & 0,188 \\
\hline $\mathrm{ONCA}_{\mathrm{t}} / \mathrm{TA}_{\mathrm{t}}$ & 0,237 & 1,015 & 0,054 & 1 & 0,815 & 1,267 \\
\hline$\Delta \mathrm{LTL}_{\mathrm{t}} / \mathrm{TA}_{\mathrm{t}}$ & 1,789 & 1,343 & 1,775 & 1 & 0,183 & 5,985 \\
\hline$\Delta \mathrm{EQE}_{\mathrm{t}} / \mathrm{TA}_{\mathrm{t}}$ & 0,322 & 1,090 & 0,087 & 1 & 0,768 & 1,380 \\
\hline FD $_{\mathbf{t}}$ & $-4,958$ & 0,472 & 110,231 & 1 & 0,000 & 0,007 \\
\hline$\Delta \mathrm{RET}_{\mathrm{t}}$ & 0,000 & 0,007 & 0,002 & 1 & 0,962 & 1,000 \\
\hline $\mathrm{DSH}_{\mathrm{t}}$ & $-0,607$ & 0,430 & 1,994 & 1 & 0,158 & 0,545 \\
\hline \multicolumn{3}{|c|}{ Podsumowanie modelu } & \multicolumn{4}{|c|}{ Test Hosmera i Lemeshowa } \\
\hline Coxa i Snella $\mathrm{R}^{2}$ & \multicolumn{2}{|c|}{ Nagelkerkego $\mathrm{R}^{2}$} & Chi-kwadrat & \multicolumn{2}{|c|}{ df } & Ist. \\
\hline 0,191 & \multicolumn{2}{|c|}{0,545} & 4,747 & \multicolumn{2}{|c|}{8} & 0,784 \\
\hline \multicolumn{7}{|c|}{ Test zbiorowy wspótczynników w modelu } \\
\hline \multicolumn{3}{|c|}{\begin{tabular}{l|l} 
Chi-kwadrat & \\
\end{tabular}} & \multicolumn{2}{|c|}{\begin{tabular}{l|l}
$\mathrm{df}$ & \\
\end{tabular}} & \multicolumn{2}{|c|}{ Ist. } \\
\hline \multicolumn{3}{|c|}{212,247} & 11 & & \multicolumn{2}{|c|}{0,000} \\
\hline
\end{tabular}

Źródło: opracowanie własne.

Ostatnim z uwzględnionych w badaniach czynników mogących potencjalnie oddziaływać na częstotliwość wykazywania dużych strat w publicznych przemysłowych spółkach akcyjnych był całokształt praktyk z zakresu realnego zarządzania wynikiem finansowym (estymowany przez zmienną TOT_REM). Przeprowadzone analizy empiryczne wykazały, że w rozpatrywanej zbiorowości można mówić o występowaniu dodatnich, istotnych ze statystycznego punktu widzenia powiązań między wartościami współczynnika całkowitego realnego zarządzania 
wynikiem finansowym TOT_REM a prawodpodobieństwem raportowania strat netto przekraczających $10 \%$ wartości aktywów ogółem przedsiębiorstwa (zob. tab. 4). Spostrzeżenie to wydaje się być szczególnie istotne z pragmatycznego punktu widzenia, bowiem współczynnik TOT_REM w sposób najbardziej holistyczny obrazuje wielość, a zarazem złożoność możliwych rozwiązań zorientowanych na „sztuczne” kształtowanie wyniku finansowego drogą real earnings management.

Warto również podkreślić, że bez względu na rozpatrywany model logistyczny, zmiennymi egzogenicznymi każdorazowo w sposób istotnie statystyczny wpływającymi na częstotliwość wystąpienia dużych strat w przedsiębiorstwach przemysłowych były: przyrost przychodów ze sprzedaży $(\triangle R E V)$ oraz wskaźnik bezpieczeństwa finansowego, ukazujący prawdopodobieństwo upadłości jednostki gospodarczej $(F D)$.

\section{PODSUMOWANIE}

Kształtowanie wyniku finansowego $\mathrm{w}$ drodze realizacji dużych strat jest jedną $\mathrm{z}$ najbardziej nietypowych strategii implementacji earnings management $\mathrm{w}$ przedsiębiorstwie. Podczas gdy większość praktyk z zakresu zarządzania zyskiem (stratą) netto w podmiocie gospodarczym ogniskuje się na przedstawianiu sytuacji finansowej jednostki w lepszym świetle w oczach jej interesariuszy, wdrażanie wielkiej kąpieli kosztowej koncentruje się na celowym obniżaniu standingu finansowego przedsiębiorstwa $\mathrm{w}$ danym roku obrachunkowym $\mathrm{z}$ jednoczesnym dążeniem do jego sztucznego podwyższania w okresach kolejnych.

Wdrażanie strategii dużych strat jako jednej z koncepcji kształtowania wyniku finansowego podmiotu gospodarczego zwykle utożsamiane jest $\mathrm{z}$ wykorzystywaniem rachunkowych technik earnings management (np. związanych z zawiązywaniem rezerw w celu zmniejszenia wykazywanego wyniku finansowego danego roku obrachunkowego i jego „przesunięcie” na późniejsze lata, w których rozwiązanie rezerw będzie $\mathrm{w}$ różnych przyczyn pożądane; tworzenie rezerw fikcyjnych). Jak pokazały zrealizowane badania empiryczne, kształtowanie big bath może następować również przy zastosowaniu rozmaitych technik rzeczowego zarządzania wynikiem finansowym.

Z analizy uzyskanych wyników badań empirycznych wynika, iż częstotliwość występowania dużych strat w przemysłowych spółkach giełdowych była w sposób istotny statystycznie uzależniona od poziomu generowanych dyskrecjonalnych kosztów produkcji czy też wartości uznaniowych operacyjnych przepływów pieniężnych. Potwierdzone zostało założenie, iż dążenia kadry kierowniczej w zakresie zwiększenia liczby wytworzonych produktów do poziomu przekraczającego oczekiwany popyt (wyrażanego za pomocą współczynnika DISC_PROD) 
oraz realizacja liberalnej polityki gospodarowania należnościami, prowadząca m.in. do spadku generowanych operacyjnych przepływów pieniężnych w stosunku do poziomu, który faktycznie mógłby zostać osiągnięty w toku ,normalnych" działań gospodarczych (uwidoczniona w wartościach miary DISC_OCF) mogą przyczyniać się do zwiększania realizowanej starty netto w spółkach poddanych analizie. Co więcej, na podstawie przeprowadzonych badań zauważono występowanie istotnych statystycznie, dodatnich zależności między wskaźnikiem obrazującym całokształt podejmowanych działań na płaszczyźnie REM (współczynnika TOT_REM) a częstotliwością big bath w spółkach prowadzących działalność wytwórczą. W ten sposób pozytywnie zweryfikować należy postawioną na wstępie hipotezą badawczą, orzekającą o występowaniu istotnych (ze statystycznego punktu widzenia) związków między wartościami współczynników $R E M$ a częstotliwością występowania dużych strat $\mathrm{w}$ publicznych przemysłowych spółkach giełdowych.

Zrealizowane analizy nie wypełniają warunku generalizacji co najmniej z dwóch względów. Po pierwsze, z racji ograniczoności próby badawczej nie mogą być uogólniane na wszystkie przedsiębiorstwa przemysłowe. Po drugie zaś, nie ma jednoznacznych dowodów, aby wszystkie wykazywane straty netto przekraczające wartość $10 \%$ sumy bilansowej traktować jako wynik ingerencji menadżerskiej w poziom raportowanych danych finansowych. Wydaje się jednak, że poczynione analizy pozwalają jednak zwrócić uwagę na potrzebę kontynuacji badań naukowych nad zagadnieniami pomiaru jakości raportowanych danych rachunkowych oraz narzędzi predykcji zróżnicowanych technik kształtowania wyniku finansowego na polskim rynku kapitałowym.

\section{BIBLIOGRAFIA}

Barth, M.E., Landsam, W.R. and Lang M.H. (2008). International Accounting Standards and Accounting Quality. Journal of Accounting Research, 46(3).

Chakravarty, A., Grewal, R. (2011). The Stock Market in The Driver's Seat! Implications for R\&D and Marketing. Management Sciences, 57(9).

Comporek, M. (2019). Urealniony wymiar oceny zarządzania zyskiem w przemysłowych spółkach giełdowych. Przedsiębiorczość i zarządzanie, XX(1), cz. 1.

Comporek, M. (2020). Kształtowanie wyniku finansowego przedsiębiorstw. Wymiary - modele ocean. Łódź: Wydawnictwo Uniwersytetu Łódzkiego.

Ewert, R. and Wagenhofer, A. (2005). Economics effect of tightening accounting standards to restrict earnings management. The Accounting Review, 80(4).

Hamrol, M., Czajka, B. i Piechocki, M. (2004). Upadłość przedsiębiorstwa-model analizy dyskryminacyjnej. Przegląd Organizacji, 6.

Kiziukiewicz, T., red. (2009). Zasoby i procesy $w$ rachunkowości jednostek gospodarczych. Warszawa: Difin.

Kmieć, D. (2015). Zastosowanie modelu logitowego do analizy czynników wpływających na bezrobocie wśród ludności wiejskiej. Ekonomika i Organizacja Gospodarki Żywnościowej, 110. 
McVay, S. (2006). Earnings Management Using Classification Shifting: An Examination of Core Earnings and Special Items. The Accounting Review, 81(3).

Mizik, N. (2010). The Theory and Practice of Myopic Management. Journal of Marketing Research, XLVII.

Piosik, A. (2016). Ksztaltowanie wyniku finansowego przez podmioty sprawozdawcze w Polsce. Katowice: Wydawnictwo Uniwersytetu Ekonomicznego w Katowicach.

Piosik, A., red. (2013). Ksztaltowanie zysków podmiotów sprawozdawczych w Polsce. MSR/MSSF a ustawa o rachunkowości. Warszawa: Wydawnictwo C.H. Beck.

Roychowdury, S. (2006). Earnings Management through Real Activities Manipulation. Journal of Accounting and Economics, 42.

Schipper, K. (1989). Commentary on Earnings Management. Accounting Horizons, 3(4).

Sellami, M. (2015). Incentives and Constraints of Real Earnings Management: The Literature Review. International Journal of Finance and Accounting, 4(4).

Tokuga, Y. and Yamashita, T. (2011). Big Bath and Management Change Big Bath and Management Change. Working Paper no. 123, Kyoto University.

Vladu, A. (2015). Managerial preferences between accrual-based versus real earnings management. Hyperion International Journal of Econophysics \& New Economy, 8(2). 